\title{
Jenis Tumbuhan Herbal dan Cara Pengolahannya (Studi Kasus Di Negeri Luhutuban Kecamatan Kepulauan Manipa Kabupaten Seram Bagian Barat)
}

\author{
Farida bahalwan $^{1}$, Nina Yuliana Mulyawati ${ }^{2}$ \\ ${ }^{1}$ Program Studi Pendidikan Biologi Universitas Darusalam Ambon \\ ${ }^{2}$ Program Studi Pendidikan Biologi IAIN Ambon \\ E-mail: idabanda@gmail.com
}

\begin{abstract}
Abstrak: Penelitian ini berawal dari penggunaan tumbuhan obat yang dipakai masyarakat Negeri Luhutuban dalam menyembuhkan berbagai jenis penyakit. Penelitian ini bertujuan untuk mengetahui jenis tumbuhan herbal dan cara mengolahnya. Jenis penelitian adalah deskritif yaitu untuk melihat jenis tumbuhan herbal dan cara mengolah sebagai obat. Objek penelitian ini adalah spesies tumbuhan obat yang dimanfaatkan oleh masyarakat setempat sebagai bahan baku obat. Subjek dalam penelitian ini adalah pembuat dan dukun beranak. Pengumpulan data dalam penelitian ini menggunakan kuesioner dan wawancara. Hasil penelitian menunjukan bahwa terdapat 51 jenis tumbuhan herbal yang telah dimanfaatkan oleh masyarakat Negeri Luhutuban sebagai obat alternatif dalam menyembuhkan berbagai jenis penyakit serta cara pengolahan tergolong sederhana, yaitu direbus, ditumbuk, diremas, oles, dipanaskan dan ditempel ataupun langsung dimakan
\end{abstract}

\section{Kata Kunci: Tumbuhan Herbal, Pengolahan, Berbagai Jenis Penyakit \\ Sorts Of Crops Herbs And Processing Way (A Case Study In The Land Of Luhutuban The Island Of Manipa)}

\begin{abstract}
Research was started with the use of a drug used herbs community Luhutuban land in the cure of various types of disease. This study aims to to know kind of herbs and how to manage it .The kind of research is descriptif which is to see what kind of herbs herbs and how to process as a remedy. The object of this research is species of plants a drug that is occupied by the local community as the raw material for a drug. A subject in this research is a maker and a traditional midwife. Was used in the study data collection during questionnaires and conducting interviews. The results of the study showed that there are 51 kind of herb that have been used by the community land Luhutuban as a remedy alternatives in cure a types of disease and the methods of processing is considered to be simple, namely boiled, pounded, crushed apply, is heated and posted or edible directly
\end{abstract}

Keywords: Plants Herbs, Processing, Various Types Of Disease

BIOLOGI SEL (YOL 7 NO 2 EDISI JUN-DES 2018 ISSN 2252-858X/E-ISSN 2541-1225)PAGE 162 
Tumbuhan herbal merupakan tumbuhan yang memiliki khasiat obat dan digunakan sebagai obat dalam penyembuhan maupun pencegahan penyakit. Pengertian berkhasiat obat adalah karena mengandung zat aktif yang berfungsi mengobati penyakit tertentu atau jika tidak mengandung zat aktif tertentu tapi mengandung efek resultan/sinergi dari berbagai zat yang berfungsi mengobati. Dalam penggunaan tumbuhan obat sebagai obat bisa dengan cara diminum, ditempel, untuk mencuci/mandi, dihirup sehingga penggunaannya dapat memenuhi konsep kerja reseptor sel dalam menerima senyawa kimia atau rangsangan (Esha, 2008).

Provinsi Maluku telah dikenal dengan sebutan "Seribu Pulau" dimana memiliki luas wilayah $712.480 \mathrm{~km}^{2}$ yang memiliki banyak potensi misalnya potensi Maluku di bidang perikanan dan pariwisata. Selain kedua potensi tersebut Maluku juga memiliki banyak keanekaragaman hayati tumbuhan herbal yang hampir di temui pada semua kabupaten. Salah satu kabupaten tersebut adalah Kabupaten Seram Bagian Barat tepatnya di Kecamatan Kepulauan Manipa Negeri Luhutuban yang memiliki beragam tumbuhan herbal namun belum teridentifikasi dengan benar. Meskipun tumbuhan herbal yang tumbuh atau di budidayakan oleh masyarakat Negeri Luhutuban belum teridentifikasi tetapi telah digunakan sebagai obat alternatif dalam menyembuhkan berbagai jenis penyakit. Tumbuhan herbal tersebut misalnya Jambu Air (Eugenia aquea Burm f) tumbuhan herbal ini dipercaya masyarakat sebagai obat batuk. Bagian yang diambil untuk menyembuhkan penyakit adalah kulit yang sudah tua.

Berbagai tumbuhan herbal telah banyak dimanfaatkan masyarakat untuk mengobati berbagi jenis penyakit dengan mengunakan alat dan cara-cara yang sangat sederhana. Pemanfaatan tumbuhan herbal tersebut sudah dilakukan oleh masyarakat yang ada pada Negeri Luhutuban di Kecamatan Kepulauan Manipa Kabupaten Seram Bagian Barat sebagai obat alternatif dalam penyembuhan berbagai jenis penyakit di antaranya demam, menurunkan panas, diare, batuk, sakit kepala, sakit pinggang, bisul, maag, patah tulang, malaria, merangsang nafsu makan dan memulihkan kekuatan setelah melahirkan serta penyakit lainnya. Sejak dahulu penggunaan tumbuhan herbal ini dilakukan sangat sederhana seperti merebus dan mengambil air dari kulit atau daun dengan cara menumbuk hingga halus serta diramu untuk menyembuhkan berbagai jenis penyakit, telah dilakukan masyarakat secara turun-temurun namun belum teridentifikasi semua. Sebagian dari jenis tumbuhan herbal yang terdapat di wilayah Negeri Luhutuban Kecamatan Kepulauan Manipa banyak belum teridentifikasi dan hanya berupa nama lokal namun sudah dimanfaatkan sebagai obat-obatan oleh masyarakat setempat sebagi obat tradisional.

\section{METODE PENELITIAN}

Jenis dalam penelitian ini adalah Deskriptif kualitatif yaitu untuk melihat jenisjenis tumbuhan herbal dan cara pengolahannya sebagai obat. Objek penelitian adalah spesies tumbuhan herbal yang dimanfaatkan oleh masyarakat setempat sebagai bahan 
pangan dan obat. Subjek penelitian adalah peramu dan dukun beranak yang menggunakan tumbuhan herbal dalam penyembuhan berbagai jenis penyakit. Dengan jumlah sampel sebanyak 7 respondent. Teknik pengumpulan data adalah (1) Kousioner (Angket) merupakan suatu alat pengumpulan data berisi daftar pertanyaan secara tertulis yang ditujukkan kepada subjek atau responden penelitian (Faisal, 2010). (2) Wawancara (interview) adalah pengumpulan data dengan mengajukan pertanyaan-pertanyaan secara langsung oleh pewawancara (pengumpul data) kepada responden, dan jawaban-jawaban responden dicatat atau di rekam dengan alat perekam (tape recorder). Teknik wawancara dapat digunakan pada responden yang buta huruf atau tidak terbiasa membaca dan menulis, termasuk anak-anak (Soehartono, 2002).

Dalam pelaksanaannya, wawancara dapat dilakukan secara bebas artinya pewawancara bebas menanyakan apa saja kepada terwawancara tanpa harus membawa lembar pedoman. Syarat wawancara (interview) seperti ini adalah pewawancara harus tetap mengingat data yang harus terkumpul (Trianto, 2011). Kemudian hasil Kousioner ini akan diintervretasi untuk mengetahui kekuatan dari pengguasaan tentang apa yang ditanyakan. Intervretasi tersebut sebagai berikut:

Tabel 1 Interpretasi Analisis Data

\begin{tabular}{|c|c|c|c|c|}
\hline Sangat Lemah & Lemah & Cukup & Kuat & Sangat Kuat \\
\hline $0-20$ & $21-40$ & $41-60$ & $61-80$ & $81-100$ \\
\hline
\end{tabular}

(Ridwan, 2003)

\section{HASIL DAN PEMBAHASAN}

Tabel 2. Hasil Pernyataan Respondent dari Pernyataan ke Satu.

\begin{tabular}{|l|c|c|c|c|c|c|}
\hline \multirow{4}{*}{ Pernyataaan } & $\begin{array}{c}\text { Inisial } \\
\text { Respondent }\end{array}$ & SS & S & RR & TS & STS \\
\hline \multirow{4}{*}{$\begin{array}{l}\text { Tumbuhan obat yang } \\
\text { digunakan untuk } \\
\text { penyembuhan berbagai } \\
\text { jenis penyakit tidak } \\
\text { diketahui masyarakat desa } \\
\text { ini }\end{array}$} & MN & $\checkmark$ & & & & \\
\hline & AS & $\checkmark$ & & & & \\
\hline & MN & $\checkmark$ & & & & \\
\hline & JP & & & & & \\
\hline & SA & $\checkmark$ & & & & \\
\hline & JS & & & $\checkmark$ & & \\
\hline & & 5 & - & 1 & 1 & - \\
\hline
\end{tabular}

Dari tabel 2, Hasil pernyataan yang didapatkan bahwa pernyataan sangat setuju sebesar $71,44 \%$, ragu-ragu sebesar $14,28 \%$ dan tidak setuju sebasar 14,28\%. Hal ini menunjukan bahwa ternyata masyarakat Negeri Luhutuban masih banyak yang belum 
mengetahui tentang pemanfaatan tumbuhan herbal dalam penyembuhan berbagai jenis penyakit dan hanya diketahui oleh dukung beranak serta tukan berobat.

Tabel 3. Hasil Pernyataan Respondent dari Pernyataan ke Dua.

\begin{tabular}{|c|c|c|c|c|c|c|}
\hline Pernyataaan & $\begin{array}{c}\text { Inisial } \\
\text { Respondent }\end{array}$ & SS & $\mathbf{S}$ & RR & $\mathrm{TS}$ & STS \\
\hline \multirow{7}{*}{$\begin{array}{l}\text { Tumbuhan obat yang digunakan } \\
\text { untuk penyembuhan berbagai } \\
\text { jenis penyakit diketahui } \\
\text { masyarakat desa ini }\end{array}$} & AN & $\checkmark$ & & & & \\
\hline & MS & & $\checkmark$ & & & \\
\hline & AS & $\checkmark$ & & & & \\
\hline & $\mathrm{MN}$ & $\checkmark$ & & & & \\
\hline & JP & $\checkmark$ & & & & \\
\hline & SA & $\checkmark$ & & & & \\
\hline & JS & $\checkmark$ & & & & \\
\hline \multirow{2}{*}{ Total } & & 6 & 1 & - & - & - \\
\hline & & $85.72 \%$ & $14,28 \%$ & - & - & - \\
\hline
\end{tabular}

Sumber: Data Hasil Penelitian

Berdasarkan tabel 3, Hasil yang didapatkan dari pernyataan yang dijawab sangat setuju sebesar $85,72 \%$ dan setuju sebesar $14,28 \%$ Jadi para respondent (dukun beranak dan tukang berobat) ini telah mendapatkan pengetahuan tentang tumbuhan yang berkahasiat obat dari keluarga atau nenek moyang secara turun temurun.

Tabel 4. Hasil Pernyataan Respondent dari Pernyataan ke Tiga.

\begin{tabular}{|c|c|c|c|c|c|c|}
\hline Pernyataaan & $\begin{array}{c}\text { Inisial } \\
\text { Respondent }\end{array}$ & SS & $\mathbf{S}$ & RR & $\mathrm{TS}$ & STS \\
\hline \multirow{7}{*}{$\begin{array}{l}\text { Masyarakat mencari } \\
\text { tumbuhan obat di hutan } \\
\text { dan di sekitar pemukiman } \\
\text { serta meramunya sendiri }\end{array}$} & AN & $\checkmark$ & & & & \\
\hline & MS & & & $\checkmark$ & & \\
\hline & AS & $\checkmark$ & & & & \\
\hline & $\mathrm{MN}$ & $\checkmark$ & & & & \\
\hline & JP & $\checkmark$ & & & & \\
\hline & SA & $\checkmark$ & & & & \\
\hline & JS & & $\checkmark$ & & & \\
\hline \multirow{2}{*}{ Total } & & 5 & 1 & 1 & - & - \\
\hline & & $71.44 \%$ & $14,28 \%$ & $14,28 \%$ & - & - \\
\hline
\end{tabular}

Sumber: Data Hasil penelitian

Tabel 4, hasil pernyataan dengan sangat setuju sebesar 71,44\%, setuju sebesar 14,28\% dan ragu-ragu sebesar 14,28\%. Menunjukkan bahwa Masyarakat Negeri Luhutuban dalam menyembuhkan berbagai jenis penyakit mencari tumbuhan yang berkhasiat obat dihutan dan sekitar pemukiman.

Tabel 5. Hasil Pernyataan Respondent dari Pernyataan ke Empat. 


\begin{tabular}{|c|c|c|c|c|c|c|}
\hline Pernyataaan & $\begin{array}{c}\text { Inisial } \\
\text { Respondent }\end{array}$ & SS & $\mathbf{S}$ & $\mathrm{RR}$ & $\mathrm{TS}$ & STS \\
\hline \multirow{7}{*}{$\begin{array}{l}\text { Banyak potensi tumbuhan } \\
\text { obat yang masih ada di } \\
\text { hutan }\end{array}$} & AN & $\checkmark$ & & & & \\
\hline & MS & $\checkmark$ & & & & \\
\hline & AS & & $\checkmark$ & & & \\
\hline & $\mathrm{MN}$ & $\checkmark$ & & & & \\
\hline & JP & $\checkmark$ & & & & \\
\hline & SA & $\checkmark$ & & & & \\
\hline & JS & $\checkmark$ & & & & \\
\hline \multirow{2}{*}{ Total } & & 6 & 1 & - & - & - \\
\hline & & $85,72 \%$ & $14,28 \%$ & & - & - \\
\hline
\end{tabular}

Sumber: Data Hasil Penelitian

Dari pernyataan tabel 5. sangat setuju $85,72 \%$ dan setuju sebesar $14,28 \%$. Membukti bahwa potensi tumbuhan herbal yang hidup dihutan masih banyak.

Tabel 6. Hasil Pernyataan Respondent dari Pernyataan ke Lima.

\begin{tabular}{|c|c|c|c|c|c|c|}
\hline Pernyataaan & $\begin{array}{c}\text { Inisial } \\
\text { Respondent }\end{array}$ & SS & $\mathbf{S}$ & $\mathrm{RR}$ & TS & STS \\
\hline \multirow{7}{*}{$\begin{array}{l}\text { Masyarakat memperoleh } \\
\text { tumbuhan obat dari hutan } \\
\text { mudah sekali }\end{array}$} & $\mathrm{AN}$ & & $\checkmark$ & & & \\
\hline & MS & & $\checkmark$ & & & \\
\hline & AS & $\checkmark$ & & & & \\
\hline & MN & & $\checkmark$ & & & \\
\hline & $\mathrm{JP}$ & $\checkmark$ & & & & \\
\hline & SA & $\checkmark$ & & & & \\
\hline & JS & $\checkmark$ & & & & \\
\hline \multirow{2}{*}{ Total } & & 5 & 2 & - & - & - \\
\hline & & $71,42 \%$ & $28,58 \%$ & & - & - \\
\hline
\end{tabular}

\section{Sumber: Data Hasil Penelitian}

Berdasarkan tabel 6, hasil pernyataan sangat setuju sebesar $71,42 \%$ dan setuju 28,58\%. bahwa masyarakat Negeri Luhutuban memperoleh tumbuhan obat dari hutan untuk menyembuhkan berbagai jenis penyakit mudah sekali.

Tabel 7. Hasil Pernyataan Respondent dari Pernyataan Enam

\begin{tabular}{|c|c|c|c|c|c|c|}
\hline \multicolumn{1}{|c|}{ Pernyataaan } & $\begin{array}{c}\text { Inisial } \\
\text { Respondent }\end{array}$ & SS & S & RR & TS & STS \\
\hline \multirow{2}{*}{$\begin{array}{l}\text { Dengan menggunakan } \\
\text { tumbuhan obat dalam } \\
\text { menyembuhkan suatu jenis }\end{array}$} & AN & $\checkmark$ & & & & \\
\hline & MS & $\checkmark$ & & & & \\
\hline & AS & $\checkmark$ & & & & \\
\hline
\end{tabular}




\begin{tabular}{|c|c|c|c|c|c|c|}
\hline $\begin{array}{l}\text { penyakit khasiatnya sangat } \\
\text { manjur }\end{array}$ & MN & $\checkmark$ & & & & \\
& JP & & $\checkmark$ & & & \\
\hline & SA & $\checkmark$ & & & & \\
\hline & JS & & $\checkmark$ & & & \\
\hline & & 5 & 2 & - & - & - \\
\hline \multirow{2}{*}{ Total } & & $71,42 \%$ & $28,58 \%$ & - & - & - \\
\hline
\end{tabular}

Sumber: Data Hasil Penelitian

Hasil pernyataan dari tabel 7, menunjukan sebesar 71,44\% sangat setuju dan $28,58 \%$ setuju. Hal ini berarti dalam penggunaan tumbuhan obat dalam peneyembuhan suatu jenis penyakit khasiatnya sangat manjur.

Tabel 8. Hasil Pernyataan Respondent dari Pernyataan ke Tujuh.

\begin{tabular}{|c|c|c|c|c|c|c|}
\hline \multicolumn{1}{|c|}{ Pernyataaan } & $\begin{array}{c}\text { Inisial } \\
\text { Respondent }\end{array}$ & SS & S & RR & TS & STS \\
\hline \multirow{4}{*}{$\begin{array}{l}\text { Pengambilan tumbuhan obat } \\
\text { tidak dilakukan secara terus- } \\
\text { menerus, tetapi } \\
\text { pengambilan hanya sekedar } \\
\text { pengobatan saja. }\end{array}$} & AN & $\checkmark$ & & & & \\
\cline { 2 - 8 } & MS & $\checkmark$ & & & & \\
\cline { 2 - 8 } & JP & $\checkmark$ & & & & \\
\cline { 2 - 8 } & SA & & $\checkmark$ & & & \\
\cline { 2 - 8 } & JS & & & & & \\
\hline & & 5 & 2 & - & - & - \\
\hline \multirow{2}{*}{ Total } & & $71,42 \%$ & 28,58 & - & - & - \\
\hline
\end{tabular}

Sumber: Data Hasil Penelitian

Berdasarkan tabel 8 , hasil penelitian dari pernyataan setuju sebesar sangat setuju sebesar 71,42\%. 28,58 \%, dan setuju sebesar 28,58 \%. Hal ini menanda bahwa proses pengambilan tumbuhan obat untuk penyembuhan berbagai jenis penyakit dilakukan hanya sekedar pengobatan saja bukan secara terus-menerus.

Tabel 9. Hasil Pernyataan Respondent dari Pernyataan ke Delapan.

\begin{tabular}{|c|c|c|c|c|c|c|}
\hline Pernyataaan & $\begin{array}{c}\text { Inisial } \\
\text { Respondent }\end{array}$ & SS & $\mathbf{S}$ & $\mathrm{RR}$ & TS & STS \\
\hline \multirow{6}{*}{$\begin{array}{l}\text { Dalam menyembuhkan suatu } \\
\text { jenis penyakit masyarakat tidak } \\
\text { hanya menggunakan satu jenis } \\
\text { tumbuhan melainkan kombinasi } \\
\text { dengan beberapa jenis } \\
\text { tumbuhan }\end{array}$} & AN & & & & $\checkmark$ & \\
\hline & MS & & $\checkmark$ & & & \\
\hline & AS & & $\checkmark$ & & & \\
\hline & MN & & & & $\checkmark$ & \\
\hline & $\mathrm{JP}$ & & $\checkmark$ & & & \\
\hline & SA & & $\checkmark$ & & & \\
\hline
\end{tabular}




\begin{tabular}{|c|c|c|c|c|c|c|}
\hline & JS & & & $\checkmark$ & & \\
\hline \multirow{2}{*}{ Total } & & - & 5 & 1 & 2 & - \\
\hline & & - & $57,14 \%$ & $14,28 \%$ & $28,58 \%$ & - \\
\hline
\end{tabular}

Sumber: Data Hasil Penelitian

Pernyataan pada tabel 9, bahwa setuju 57,14\% menggunakan satu jenis tumbuhan oleh peramu dalam menyembuhkan suatu jenis penyakit tertentu, ragu-ragu $14,28 \%$ dan tidak setuju 28,58\%

Tabel 10. Hasil Pernyataan Respondent dari Pernyataan ke Sembilan.

\begin{tabular}{|c|c|c|c|c|c|c|}
\hline Pernyataaan & $\begin{array}{c}\text { Inisial } \\
\text { Respondent }\end{array}$ & SS & $\mathbf{S}$ & RR & $\mathrm{TS}$ & STS \\
\hline \multirow{7}{*}{$\begin{array}{l}\text { Semua bagian tumbuhan obat } \\
\text { dimanfaatkan untuk } \\
\text { pengobatan dalam } \\
\text { menyembuhkan penyakit }\end{array}$} & $\mathrm{AN}$ & & & & $\checkmark$ & \\
\hline & MS & & & & $\checkmark$ & \\
\hline & AS & & & & $\checkmark$ & \\
\hline & $\mathrm{MN}$ & & & $\checkmark$ & & \\
\hline & JP & & & & $\checkmark$ & \\
\hline & SA & & $\checkmark$ & & & \\
\hline & JS & & $\checkmark$ & & & \\
\hline \multirow{2}{*}{ Total } & & - & 2 & 1 & 4 & - \\
\hline & & - & $28,57 \%$ & $14,28 \%$ & $57,15 \%$ & - \\
\hline
\end{tabular}

\section{Sumber: Data Hasil Penelitian}

Dari tabel 10, hasil pernyataan sebesar $28,57 \%$ setuju bahwa Semua bagian tumbuhan obat dimanfaatkan untuk pengobatan dalam menyembuhkan penyakit, ragu-ragu $14,28 \%$ dan tidak setuju $57,15 \%$.

Tabel 11. Hasil Pernyataan Respondent dari Pernyataan ke Sepuluh.

\begin{tabular}{|c|c|c|c|c|c|c|}
\hline Pernyataaan & $\begin{array}{c}\text { Inisial } \\
\text { Respondent }\end{array}$ & SS & S & RR & TS & STS \\
\hline \multirow{5}{*}{$\begin{array}{l}\text { Untuk meramu tumbuhan } \\
\text { obat biasanya dilakukan } \\
\text { dengan cara rebus }\end{array}$} & AN & $\checkmark$ & & & & \\
\hline & MS & & & $\checkmark$ & & \\
\hline & AS & & & & $\checkmark$ & \\
\hline & MN & & & & $\checkmark$ & \\
\hline & JP & & & & $\checkmark$ & \\
\hline & SA & & & & $\checkmark$ & \\
\hline & JS & & & & $\checkmark$ & \\
\hline & & 1 & - & 1 & 5 & - \\
\hline & & $14,28 \%$ & - & $14,28 \%$ & $71,44 \%$ & - \\
\hline \multirow{2}{*}{ Total } & & & & &
\end{tabular}

Sumber: Data Hasil Penelitian 
Berdasarkan tabel 11, hasil yang diperoleh dari pernyataan cara meramu tumbuhan obat dengan direbus sangat setuju sebesar 14,28\%, ragu-ragu sebesar 14,28\% dan tidak setuju sebesar $71,44 \%$.

Tabel 12. Hasil Pernyataan Respondent dari Pernyataan ke Sebelas.

\begin{tabular}{|c|c|c|c|c|c|c|}
\hline Pernyataaan & $\begin{array}{c}\text { Inisial } \\
\text { Respondent }\end{array}$ & SS & $\mathbf{S}$ & $\mathrm{RR}$ & $\mathrm{TS}$ & STS \\
\hline \multirow{7}{*}{$\begin{array}{l}\text { Tidak semua bagian } \\
\text { tumbuhan obat digunakan } \\
\text { dalam menyembuhkan suatu } \\
\text { jenis penyakit? }\end{array}$} & $\mathrm{AN}$ & & $\checkmark$ & & & \\
\hline & MS & & $\checkmark$ & & & \\
\hline & AS & $\checkmark$ & & & & \\
\hline & $\mathrm{MN}$ & $\checkmark$ & & & & \\
\hline & JP & $\checkmark$ & & & & \\
\hline & SA & $\checkmark$ & & & & \\
\hline & JS & $\checkmark$ & & & & \\
\hline \multirow{2}{*}{ Total } & & 5 & 2 & - & - & - \\
\hline & & $71,42 \%$ & $28,58 \%$ & - & - & - \\
\hline
\end{tabular}

Sumber: Data Hasil Penelitian

Dari hasil tabel 12, pernyataan sangat setuju tentang tidak semua bagian tumbuhan obat digunakan dalam menyembuhkan suatu jenis penyakit sebesar 71,43\%.dan tidak setuju sebesar $28,57 \%$.

Tabel 13. Hasil Pernyataan Respondent dari Pernyataan ke Dua Belas.

\begin{tabular}{|l|c|c|c|c|c|c|}
\hline \multicolumn{1}{|c}{ Pernyataaan } & $\begin{array}{c}\text { Inisial } \\
\text { Respondent }\end{array}$ & SS & S & RR & TS & STS \\
\hline $\begin{array}{l}\text { Tumbuhan obat diramu dan } \\
\text { diminum setiap hari serta } \\
\text { memililiki dosis yang sama dalam } \\
\text { menyembuhkan suatu jenis } \\
\text { penyakit }\end{array}$ & AN & & $\checkmark$ & & & \\
\hline & MS & & $\checkmark$ & & & \\
\hline & MN & & & & $\checkmark$ & \\
\hline & JP & & & & $\checkmark$ & \\
\hline & SA & & & & $\checkmark$ & \\
\hline & JS & & & & $\checkmark$ & \\
\hline & & & & & $\checkmark$ & \\
\hline & & - & $28,56 \%$ & - & $71,44 \%$ & - \\
\hline
\end{tabular}

\section{Sumber: Data Hasil Penelitian}

Pada tabel 13, hasil pernyataan pernyataan menunjukkan bahwa sebesar 28,56\% setuju terhadap semua bagian tumbuhan obat digunakan dalam menyembuhkan berbagai jenis penyakit dan $71,44 \%$ tidak setuju. 
Tabel 14. Hasil Pernyataan Respondent dari Pernyataan ke Tiga Belas

\begin{tabular}{|l|c|c|c|c|c|c|}
\hline \multirow{4}{*}{ Pernyataaan } & $\begin{array}{c}\text { Inisial } \\
\text { Respondent }\end{array}$ & SS & S & RR & TS & STS \\
\hline \multirow{5}{*}{$\begin{array}{l}\text { Semua jenis penyakit } \\
\text { dapat di sembuhkan } \\
\text { dengan tumbuhan obat }\end{array}$} & AN & $\checkmark$ & & & & \\
\hline & MS & $\checkmark$ & & & & \\
\hline & MN & $\checkmark$ & & & & \\
\hline & JP & $\checkmark$ & & & & \\
\hline & SA & $\checkmark$ & & & \\
\hline & JS & $\checkmark$ & & & & \\
\hline & & 6 & - & - & 1 & \\
\hline \multirow{2}{*}{ Total } & & $85,72 \%$ & - & - & $14,28 \%$ & \\
\hline
\end{tabular}

Sumber: Data Hasil Penelitian

Berdasarkan tabel 14 hasil penyataan $85,72 \%$ sangat setuju semua jenis penyakit dapat di sembuhkan dengan tumbuhan obat, dan tidak setuju 14,28\%.

Tabel 15. Hasil Pernyataan Respondent dari Pernyataan ke Empat Belas.

\begin{tabular}{|c|c|c|c|c|c|c|}
\hline \multirow{2}{*}{ Pernyataaan } & $\begin{array}{c}\text { Inisial } \\
\text { Respondent }\end{array}$ & SS & S & RR & TS & STS \\
\hline \multirow{4}{*}{$\begin{array}{l}\text { Semua masyarakat sudah } \\
\text { membudidakan tumbuhan } \\
\text { yang diketahui berkhasiat } \\
\text { obat }\end{array}$} & AN & & & & $\checkmark$ & \\
\hline & MS & & $\checkmark$ & & & \\
\hline & MS & & $\checkmark$ & & & \\
\hline & JP & & & & $\checkmark$ & \\
\hline & SA & & & & $\checkmark$ & \\
\hline & JS & & $\checkmark$ & & & \\
\hline & & - & 3 & - & 4 & - \\
\hline \multirow{2}{*}{ Total } & & - & $42,86 \%$ & - & $57,14 \%$ & - \\
\hline
\end{tabular}

Sumber: Data Hasil Penelitian

Pada tabel 15 hasil penyataan $42,86 \%$ setuju bahwa Semua masyarakat sudah membudidakan tumbuhan yang diketahui berkhasiat obat dan 57,14\% tidak setuju. Tabel 16. Hasil Pernyataan Respondent dari Pernyataan ke Lima Belas.

\begin{tabular}{|l|c|c|c|c|c|c|}
\hline \multicolumn{1}{|c|}{ Pernyataaan } & $\begin{array}{c}\text { Inisial } \\
\text { Respondent }\end{array}$ & SS & S & RR & TS & STS \\
\hline \multirow{2}{*}{$\begin{array}{l}\text { Dengan menggunakan } \\
\text { tumbuhan obat dalam } \\
\text { menyembuhkan suatu jenis }\end{array}$} & AN & $\checkmark$ & & & & \\
\cline { 2 - 7 } & MS & $\checkmark$ & & & & \\
\cline { 2 - 8 } & AS & $\checkmark$ & & & & \\
\hline
\end{tabular}




\begin{tabular}{|c|c|c|c|c|c|c|}
\hline \multirow{3}{*}{$\begin{array}{l}\text { penyakit tidak menimbulkan } \\
\text { efek samping }\end{array}$} & MN & $\checkmark$ & & & & \\
\hline & JP & $\checkmark$ & & & & \\
\hline & SA & & & & $\checkmark$ & \\
\hline & JS & $\checkmark$ & & & & \\
\hline \multirow{2}{*}{ Total } & & 6 & - & - & 1 & - \\
\hline & & $85,72 \%$ & - & - & $14,28 \%$ & - \\
\hline
\end{tabular}

Sumber: Data Hasil Penelitian

Dari tabel 16, dari hasil penyataan $85,72 \%$ sangat setuju bahwa dengan menggunakan tumbuhan obat dalam menyembuhkan suatu jenis penyakit tidak menimbulkan efek samping, dan 14,28\% tidak setuju

\section{PEMBAHASAN}

Dari hasil identifikasi ditemukan bahwa terdapat 51 jenis tumbuhan herbal yang telah dimanfaatakan oleh masyarakat Negeri Luhutuban dalam penyembuhan berbagai jenis penyakit. Populasi tumbuhan herbal yang banyak ditemukan adalah tumbuhan Meniran (Phyllanthus urinaria L). Tumbuhan ini banyak dimanfaat oleh masyarakat dalam menyembuhkan penyakit. Sementara tumbuhan Sawi Langit (Vernonia cinerea L) sulit untuk ditemukan karena kurang dimanfaatkan dan kondisi tanah yang tidak cocok. Tumbuhan herbal yang tumbuh dikenal masyarakat setempat masih dengan menggunakan nama lokal setelah diidentifikasi dengan nama nasional dan nama ilmiah seperti tumbuhan Jadam dengan nama nasional sambiloto (Andrographis paniculata Ness). Beberapa jenis tumbuahan obat dikenal dengan nama lokal yang berbeda-bada pada setiap daerah. Sebagai contoh Pegagan (Cantela asiatica) dengan nama daerah daun kaki kuda, daun pengaangga, pegago (Melayu, Sumatera), pegaga (Ujung Pandang, Aceh), ampagaga (Batak), antanan gede, antana rambat (Sunda), pegagan, gagan-gagan, ganggagan, antana, cowet gompeng, panigowang, pategowang, calingan rambat, rending,kero batok (Jawa), kos tekosan (Madura), taidah (Bali), bebele, paiduh (Nusa Tenggara), wisu-wisu, kisu-kisu (Sulawesi), kori-kori (Halmahera), dau tungke (Bugis), Pagaga (Makassar), kolotidi (Ternate), dan (Irian) sandanan, dogauke (Anonim, 2009).

Cara pengolahan dan penggunaan tumbuhan obat oleh masyarakat di Negeri Luhutuban tergolong sederhana, yaitu direbus, ditumbuk, diremas-remas, dibalurkan, dipanaskan dan ditempel ataupun langsung dimakan. Dosis pengobatan pun hanya berdasarkan kebiasaan ataupun ukuran tubuh pasien. Sebagai contoh pada pemanfaatan batang Jarak Pagar (Jatropha curcas L) yang diambil batang berukuran $15 \mathrm{~cm}$ kemudian direbus. Dengan demikian cara pengolahan tumbuhan obat secara tradisional biasa dilakukan dengan cara direbus, namun ada juga tumbuhan yang cara peramuannya ditumbuk atau dihaluskan (Salim, 1992).

Jenis-jenis tumbuhan herbal yang dimanfaatkan secara tradisional oleh masyarakat belum dikenal dan dikembangkan serta dibuktikan mengenai kandungan 
fitokimianya. Data dan informasi ini menjadi sangat penting untuk didokumentasikan sehingga dapat diketahui oleh generasi berikutnya, mengingat belum adanya dokumentasi tentang tumbuhan obat di Kecamatan Kepulauan Manipa khususnya Negeri Luhutuban yang memiliki kandungan bahan aktif yang terkandung dalam jenisjenis tumbuhan obat tersebut.

Dari hasil penelitian dapat diketahui bahwa tidak semua masyarakat mengetahui tentang tumbuhan obat yang digunakan untuk penyembuhan berbagai jenis penyakit penyakit. Hal tersebut dapat dilihat pada pernyataan setuju kuat yakni dengan persentase $71,44 \%$, kemudian ragu-ragu sangat lemah yakni dengan persentase 14,28\% dan selanjutnya tidak setuju sangat lemah juga dengan memilki persentase 14,28\%. Pengetahuan tentang tumbuhan yang berkhasiat obat di Negeri Luhutuban hanyalah dimiliki oleh para tukang berobat/dukun beranak. Pada umumnya masyarakat biasanya mereka datang untuk meminta resep jenis-jenis tumbuhan yang akan digunakan untuk menyembuhkan penyakit tersebut misalnya, sakit dada atau orang pasca melahirkan.

Para responden menyatakan bahwa pengetahuan mengenai tumbuhan yang berkhasiat obat didapatkan dari keluarga atau nenek moyang secara turun-temurung. Hal ini dapat dilihat dari jawaban pernyataan sangat setuju sangat kuat yakni dengan persentase sangat setuju sebesar $85,72 \%$ dan setuju sangat lemah dengan persentase sebesar $14,28 \%$. Pengetahuan mengenai jenis-jenis tumbuhan yang berkasiat obat dan cara pengobatan tradisional tersebut hanya bisa diwariskan pada keluarga secara turun temurun bahkan pada orang lain yang memiliki niat besar dan kemauan yang tinggi untuk mempelajarinya. Pemanfaatan tumbuhan dalam pengobatan tradisional masih mengandalkan pada warisan pengetahuan turun-temurun. Sistem pewarisan ini bersifat tertutup dalam satu garis keturunan atau keluarga (Trubus, 2010).

Setelah mengetahui khasiat tumbuhan obat dan meramu dari Peramu/dukun beranak masyarakat mencari tumbuhan tersebut di hutan dan di sekitar pemukiman serta meramunya sendiri. Pernyataan ini dapat dilihat dari jawaban respondent sangat setuju kuat dengan persentase sebesar $71,44 \%$, setuju sangat lemah dengan persentase sebesar $14,28 \%$ dan ragu-ragupun sangat lemah dengan persentase sebesar 14,28\%. Masyarakat yang ada di Negeri Luhutuban baik yang tinggal dipesisir pantai maupun yang tinggal di dekat hutan mereka pergi kehutan dan sekitar pemukiman untuk mencari dan mengambil jenis-jenis tumbuhan yang akan digunakan serta meramunya sendiri dalam menyembuhkan suatu jenis penyakit

Dengan luas wilayah yang begitu besar $\left(50,29 \mathrm{~km}^{2}\right)$ ternyata hutan yang ada di Negeri luhutuban memilki banyak potensi tumbuhan obat yang tumbuh dan dimanfaatkan oleh masyarakat setempat. Potensi tumbuhan obat ini didasari pada jawaban renpondent sangat setuju sangat kuat yakni memperoleh persentase $85,72 \%$ dan setuju sangata lemah dengan persentase $14,28 \%$. Potensi tumbuhan tersebut misalnya pohon pule/pulai (Astronia Scholaris R. Br). Tumbuhan yang memiliki karakter pohon berkayu, tingginya 
bisa mencapai kurang lebih 7-12 meter. Daun berbentuk bulat dengan permukaan licin dan mempunyai getah berwarna putih susu ini banyak dijumpai dihutan baik pada daerah pengunungan maupun daerah datar.

Masyarakat mudah sekali memperoleh tumbuhan obat dihutan, hal ini dapat dilihat bahwa pernyatan sangat setuju sangat setuju kuat dengan persentase sebesar $71,42 \%$ dan setuju lemah dengan persentase sebesar 28,58\%. Kemudahan dalam memperoleh jenis-jenis tumbuhan yang berkhasiat sebagai obat dalam penyembuhan suatu jenis penyakit yang ada di Negeri Luhutuban disebabkan karena Potensi tumbuhan obat yang hidup dihutan begitu banyak. Tumbuhan obat menjadi alternatif obat yang paling muudah dicari sebab tanaman ditanaman dipekarangan rumah sebgai Obat keluarga (Muhlisah, 2007)

Selain mudah, para rensponden menyatakan bahwa dengan menggunakan tumbuhan obat dalam menyembuhkan suatu jenis penyakit khasiatnya sangat manjur. Disini bisa dilihat dari pernyataan yang didapat sangat setuju kuat dengan persentase $71,44 \%$ dan setuju lemah dengan persentase $28,58 \%$. Hal ini didasari oleh masyarakat dalam melakukan pengobatan berdasarkan pengalaman yang telah mereka lihat sejak dahulu. Tumbuhan obat yang masih berupa simplisia, hasil pengobatannya tmpak lambat namun sifat konstruktif dan membangun (Dalimartha, 1999)

Berdasarkan pernyataan ke tujuh bahwa pengambilan tumbuhan obat tidak dilakukan secara terus-menus, hanya sekedar pengobatan saja. Dimana Hal ini sesuia dengan pernyataan dari jawaban pernyataan sangat setuju kuat dengan persentase $71,42 \%$ dan setuju lemah dengan persentase $28,58 \%$. Hal tersebut dikarena untuk menjaga tumbuhan agar tidak punah. Misalnya pada tumbuhan yang bagian kulit dan akar yang digunakan sebagai obat dalam penyembuhan penyakit tertentu. Hal tersebut juga dikemukakkan oleh (Noorhidayah \& Sidiyasa, 2005) bahwa pemanfaatan pohon sebagai tumbuhan obat dapat menjadi ancaman karena ada kemungkinan jenis-jenis tersebut akan terganggu atau punah akibat pengambilan bahan obat oleh masyarakat secara berlebihan.

Dalam menyembuhkan suatu jenis penyakit masyarakat tidak hanya menggunakan satu jenis tumbuhan melainkan kombinasi dengan beberapa jenis tumbuhan. Bisa dilahat bahwa pernyataan setuju cukup yakni persentase 57,14\%, ragu-ragu sangat lemah yakni persentase $14,28 \%$ dan tidak setuju lemah yakni persentase $28,58 \%$. Namun ada beberapa jenis tumbuhan yang digunkan tanpa kombinasi dengan tumbuhan lain, misalnya ketepeng cina, daun sembung, srikaya, daun kentut dan lainnya sebagainya. Berdasarkan hasil penelitian dari pernyataan kesembilan, semua jenis tumbuhan obat digunakan dalam menyembuhkan berbagai jenis penyakit. Hal ini dilihat berdasarkan jawaban yang didapat tidak setuju cukup dengan persentase $57,15 \%$, ragu-ragu snagat lemah dengan persentase $14,28 \%$ dan setuju lemah kuat dengan persentase 28,57\%. Hal ini terkait dengan kesedian jenis tanaman tertentu dialam terbatas. Contohya seperti buah delima, tanaman ini memiliki khasiat pada akar dalam menyembuhkan penyakit sakit perut. Maka masyarakat 
tidak menggunakan tumbuhan tesebut dalam pengobatan melainkan memilih jenis tumbuhan lain. Dari sisi konservasi, penggunaan akar sebagai bahan baku obat akan mengganggu kelangsungan hidup tumbuhan dan kemungkinan menyebabkan kematian karena bagian akarnya diambil (Noorhidayah \& Sidiyasa, 2005).

Sementara untuk hasil penelitian pernyataan kesepuluh, dalam meramu tumbuhan obat biasanya dilakukan dengan cara rebus, tumbuk dan tempel. Hal ini disebabkan dari jawaban yang didapat dari pernyataan tidak setuju kuat yakni dengan persentase sebesar $71,44 \%$ sangat setuju sangat lemah dengan persentase sebesar 14,28\%, kemudian raguragupun sangat lemah dengan persentase sebesar 14,28\%. Dengan demikian cara pengolahan tumbuhan obat didasrkan pada jenis penyakit dan tumbuhan.

Dari hasil pernyataan ke sebelas tidak semua bagian tumbuhan obat digunakan dalam menyembuhkan berbagai jenis penyakit. Hal ini disebabkan dari jawaban yang didapat dari pernyataan sangat setuju kuat dengan persentase sebesar 71,43\% 50\%, dan setuju lemah dengan persentase sebesar $28,57 \%$. Hal ini menunjukan bahwa penggunaan tumbuhan obat dalam menyembuhkan suatu jenis penyakit hanya menggunakan bagian tertentu saja saja, contoh pulai tanaman ini hanya diambil kulit batang dan kulit cabang. Dalam kulit batang dan kulit cabang berkandungan zat-zat alkaloida ditamina, ditaina dan lainnya. Dengan dosis 0,25 gram 0,50 gram digunakan sebagi obat antimalaria (Kartasapoetra, 2004)

Berdasarkan hasil penelitian menyatakan bahwa tidak semua tumbuhan obat yang diramu dan diminum setiap hari serta memiliki dosis yang sama dalam menyembuhkan suatu jenis penyakit. Disebabkan karena hasil pernyatan tidak setuju kuat persentase yakni 71,44\% dan setuju lemah persentase yakni $28,56 \%$. Hal disebabkan karena penngunaan cara meramu tumbuhan obat berdasarkan jenis penyakit dan kondisi tubuh pasien. Hasil penyataan ke ketiga belas bahwa semua semua jenis penyakit dapat disembuhkan dengan tumbuhan obat. Hal ini mengacu pada jawaban responden dimana sangat setuju sangat kuat dengan persentase $85,72 \%$, dan tidak setuju sangat lemat dengan persentase $14,28 \%$. Hal ini menandakan bahwa Keampuhan pengobatan dengan menggunakan tumbuhan herbal telah banyak dibuktikan melalui berbagai pengalaman. Berbagai jenis penyakit yang tidak dapat disembuhkan melalui pengobatan alopati (kedokteran), ternyata masih bisa di atasi dengan pengobatan yang menggunakan bahan-bahan dari tumbuhan herbal, misalnya penyakit kanker dan kelumpuhan serta penyakit lainnya (Utami, 2013).

Berdasarkan hasil penyataan ke empat belas semua masyarakat sudah membudidakan tumbuhan yang diketahui berkhasiat obat, Dari hasil penyataan $42,86 \%$ dan tidak setuju cukup dengan memperoleh persentase 57,14\%. Masih banyak jenis-jenis tumbuhan obat yang belum diketahui cara budidayanya secara umum dan banyak pula petani ini Indonesia yang belum membudidayakan tanaman obat secara intensif (Agromedia, 2008). Pada hasil penelitian kelima belas pernyataan dengan menggunakan tumbuhan obat dalam menyembuhkan suatu jenis penyakit tidak menimbulkan efek 
samping. Hasil penyataan sangat setuju sangat kuat dengan persentase $85,72 \%$, dan tidak setuju sangat lemah dengan persentase 14, 28\%. Penggunaan tumbuhan obat dalam penyembuhan berbagai jenis penyakit tidak menimbul efek samping jika penggunaannya sesuai dengan dosis. Menurut (Thomas, 1989) bahwa penggunaan obat tradisional ini tidak memiliki efek samping.

\section{KESIMPULAN}

Setelah dilakukan penelitian terhadap identifikasi jenis-jenis tumbuhan herbal dan cara pengolahannya untuk menyembuhkan berbagai jenis penyakit di Negeri Luhutuban dapat disimpulkan bahwa: (1) Terdapat 51 spesies tumbuhan herbal yang dimanfaatkan oleh masyarakat dalam menyembuhkan berbagai jenis penyakit, (2) Cara pengolahan dan penggunaan tumbuhan obat oleh masyarakat di Negeri Luhutuban tergolong sederhana, yaitu direbus, ditumbuk, diremas-remas dibalurkan, dipanaskan dan ditempel ataupun langsung dimakan. Dosis pengobatan pun hanya berdasarkan kebiasaan ataupun ukuran tubuh pasien

\section{SARAN}

1. Perlu dilakukan penelitian lanjutan untuk mengetahui komponen bioaktif serta bioaktifitasnya sehingga pemanfaatan tumbuhan herbal yang telah dimanfaatkan masyarakat secara tradisional dapat terbukti secara ilmiah dalam menyembuhkan berbagai jenis penyakit.

2. Perlu dilakukan pembudidayaan terhadap tumbuhan herbal yang telah dimanfaatkan oleh masyarakat dalam penyembuhan berbagai jenis penyakit sehingga tumbuhan herbal tersebut tidak mengalami kepunahan.

\section{DAFTAR PUSTAKA}

Achmadi, Umar Fahmi. 2005. Manajemen Penyakit Berbasis Wilayah. Cetakan I. Buku Kompas. Jakarta

Agromedia. R .2008. Buku pintar tanaman obat. PT. Agromedia Pustaka. Ciganjur, Jagakarsa, Jakarta Selatan

Astika, Ayu. 2013. Khasiat Selangit Manggis dan Sirsak Tumpas Beragam Penyakit. Cetakan I. Araska. Bantul, Yogyakarta

Dalirmartha, S. 1999. Atlas tumbuhan obat Indonesia jilid 1. Cetakan I. Trubus Agriwidya. Jakarta:

Jakarta

Dewi, Nurfita. 2013. Khasiat dan Cara Olah Sambiloto untuk Menumpas Berbagai Penyakit. Pustaka Baru Press. Baturetno, Bangun Tapan, Bantul, Yogyakarta

Dharma, A.P. 1985. Tanaman Obat Tradisional Indonesia. Balai Pustaka. Jakarta 
Faisal, Sanapiah. 2010. Format-format Penelitian Sosial. Rajawali Pers. Jakarta

Farida, Yenni. 2012. Ensiklopedia Tanaman Obat Nusantara.cetakan I. Araska. Yogyakarta.

Hanafiah, M. Jusuf \& Amri Amir. 1999. Etika Kedokteran dan Hukum. Buku Kedokteran EGC. Jakarta

Harryana, Eren dkk. 2013. Daun Ampuh Basmi Penyakit Cetakan I. Jogjakarta: Nusa Creativa

Katno \& Pramono S. 2006. Tingkat Manfaat dan Keamanan Tanaman Obat dan Obat Tradisional.

Balai Penelitian Tanaman Obat Tawangmangu. FakultasFarmasi UGM. Yogyakarta

Kartasapoetra. 2004. Tumbuhan Berkhasiat Obat. PT Rineka Cipta. Jakarta

Muhlisah, Fauziah. 2007. Tanaman Obat Keluarga (Toga). Penerba Swadaya. Jakarta

Nurmalina, Rina \& Bandung Valley. 2012. Herbal Legendaris Untuk Kesehatan Anda. PT. Elex Media Komputindo. Jakarta

Purwanto, Budhi. 2013. Herbal dan Keperawatan (Teori, Praktek, Hukum dalam Keperawatan). Nuha Medika. Yogyakarta

Radji, Maksum: 2005. Peranan Bioteknologi dan Mikroba Endofit dalam Pengembangan Obat Herbal. Majalah Ilmu Kefarmasian, Vol. II, No.3, Departemen Farmasi, FMIPA-UI. Jakarta

Ridwan. 2003. Analisis Variabel-variabel Penelitian. Universitas Gajah Mada. Jogjakarta Rukmana, Rahmat. 1994. Kunyit. Cetakan ke-1. Kanisius. Yogyakarta

Salim, S. 1992. Petunjuk Pengobatan dengan Resep-resep Asli. CV Aneka: Solo

Sakri, Faisal M. 2012. 101 Khasiat dan Mamfaat Jamu Godog untuk Segala Macam Penyakit. Cetakan I. Diandra Pustaka Indonesia. Yogyakarta

Soehartono, Irawan. 2002. Metode Penelitian Sosial (suatu penelitian bidang kesejahteraan social dan ilmu social lainnya). PT Remaja Rosdakarya. Bandung

Sukandar, E. Y. 2004. Tren dan Paradigma Dunia Farmasi: Industri-Klinik Teknologi Kesehatan. Orasi Ilmiah Dies Natalis ITB ke 45, ITB. Bandung

Supriadi, dkk. 2001. Tumbuhan obat Indonesia penggunaan dan khasiatnya. Pustaka Populer Obor. Jakarta

Thomas, A.N.S. 1989. Tanaman Obat Tradisional. Kanisius. Jakarta 1992. Tanaman Obat Tradisional 2. Kasinus. Yogyakarta:

Trianto: 2011. Pengantar Penelitian bagi Pengembangan Profesi Pendidikan dan Tenaga Kependidikan. Cetakan ke II. Kencana. Jakarta

Trubus. 2010. Herbal Indonesia Berkhasiat Bukti Ilmiah dan Cara Racik. PT Trubus Swadaya. Bogor

Utami, Prapti. 2013. The Miracle Of Herbs. Cetakan I. Agromedia Pustaka. Jakarta: Wasito, Hendri: 2008. Obat Tradisional Kekayaan Alam. Graham Ilmu. Jogjakarta 
Widyaningrum, Herlina dan Tim Solusi Alternatif 2011. Kitab Tanaman Obat Nusantara. Cetakan I. Media Pressindo. Yogyakarta

Yuliani, S. 2001. Prospek Pengembangan Obat Tradisional Menjadi Obat Fitofarmaka. Jurnal Litbang Pertanian, Balai Penelitian Tanaman Rempah dan Obat. Bogor 